\title{
The Yale Library of Military History
}

Donald Kagan and Frederick Kagan, Series Editors 
This page intentionally left blank 


\title{
War \\ by Land, Sea, and Air \\ Dwight Eisenhower and the Concept of Unified Command
}

\author{
DAVID JABLONSKY \\ Series Foreword by \\ Donald Kagan and Frederick Kagan
}

\section{Yale}

UNIVERSITY PRESS

New Haven and London 
Published with assistance from the Kingsley Trust Association Publication Fund established by the Scroll and Key Society of Yale College.

Copyright (C) 2010 by David Jablonsky.

All rights reserved.

This book may not be reproduced, in whole or in part, including illustrations, in any form (beyond that copying permitted by Sections 107 and 108 of the U.S. Copyright Law and except by reviewers for the public press), without written permission from the publishers.

Designed by James J. Johnson and set in Fairfield Medium type by Tseng Information Systems, Inc.

Printed in the United States of America by Sheridan Books, Ann Arbor, Michigan.

\section{Library of Congress Cataloging-in-Publication Data}

Jablonsky, David.

War by land, sea, and air : Dwight Eisenhower and the concept of unified command /

David Jablonsky.

p. cm. - (The Yale library of military history)

Includes bibliographical references and index.

ISBN 978-0-300-15389-7 (cloth : alk. paper) I. Eisenhower, Dwight D. (Dwight David), I890-1969-Military leadership. 2. Unified operations (Military science) - History2oth century. 3. Combined operations (Military science)-History-2oth century. 4. Allied Forces-Organization. 5. World War, 1939-1945-Campaigns-Western Front. 6. North Atlantic Treaty Organization-Armed Forces-Organization. 7. United StatesArmed Forces-Organization. 8. United States. Joint Chiefs of Staff-ChairmenHistory - 2oth century. 9. United States-Military policy. Io. United States-History, Military-2oth century. I. Title.

E836.J24 2010

$973.921092-\mathrm{dc} 22$

[B]

A catalogue record for this book is available from the British Library.

This paper meets the requirements of ANSI/NISO z39.48-1992 (Permanence of Paper).

$\begin{array}{llllllllll}\text { I0 } & 9 & 8 & 7 & 6 & 5 & 4 & 3 & 2 & \text { I }\end{array}$ 
For Kyra and Dave with great love and pride

For, lo, the winter is past,

The rain is over and gone;

The flowers appear on the earth;

The time of the singing of birds is come,

And the voice of the turtle is heard in our land.

-Song of Solomon 
This page intentionally left blank 